IZA DP No. 6510

Mind the Gap: Net Incomes of Minimum Wage Workers in the EU and the US

Ive Marx

Sarah Marchal

Brian Nolan

April 2012 


\title{
Mind the Gap: Net Incomes of Minimum Wage Workers in the EU and the US
}

\author{
Ive Marx \\ CSB, University of Antwerp \\ and IZA \\ Sarah Marchal \\ CSB, University of Antwerp \\ Brian Nolan \\ University College Dublin
}

\section{Discussion Paper No. 6510 \\ April 2012}

IZA
P.O. Box 7240
53072 Bonn
Germany

Phone: +49-228-3894-0

Fax: +49-228-3894-180

E-mail: iza@iza.org

\begin{abstract}
Any opinions expressed here are those of the author(s) and not those of IZA. Research published in this series may include views on policy, but the institute itself takes no institutional policy positions.

The Institute for the Study of Labor (IZA) in Bonn is a local and virtual international research center and a place of communication between science, politics and business. IZA is an independent nonprofit organization supported by Deutsche Post Foundation. The center is associated with the University of Bonn and offers a stimulating research environment through its international network, workshops and conferences, data service, project support, research visits and doctoral program. IZA engages in (i) original and internationally competitive research in all fields of labor economics, (ii) development of policy concepts, and (iii) dissemination of research results and concepts to the interested public.
\end{abstract}

IZA Discussion Papers often represent preliminary work and are circulated to encourage discussion. Citation of such a paper should account for its provisional character. A revised version may be available directly from the author. 


\section{ABSTRACT \\ Mind the Gap: \\ Net Incomes of Minimum Wage Workers in the EU and the US}

This paper focuses on the role of minimum wages, tax and benefit policies in protecting workers against financial poverty, covering 21 European countries with a national minimum wage and three US States (New Jersey, Nebraska and Texas). It is shown that only for single persons and only in a number of countries, net income packages at minimum wage level reach or exceed the EU's at-risk-of poverty threshold, set at 60 per cent of median equivalent household income in each country. For lone parents and sole breadwinners with a partner and children to support, net income packages at minimum wage are below this threshold almost everywhere, usually by a wide margin. This is the case despite shifts over the past decade towards tax relief and additional income support provisions for low-paid workers. We argue that there appear to be limits to what minimum wage policies alone can achieve in the fight against in-work poverty. The route of raising minimum wages to eliminate poverty among workers solely reliant on it seems to be inherently constrained, especially in countries where the distance between minimum and average wage levels is already comparatively small and where relative poverty thresholds are mostly a function of the dual-earner living standards. In order to fight in-work poverty new policy routes need to be explored. The paper offers a brief discussion of possible alternatives and cautions against 'one size fits all' policy solutions.

JEL Classification: $\quad$ 13, H2, J8

Keywords: $\quad$ minimum wage, poverty, taxes, social transfers, subsidies

Corresponding author:

Ive Marx

Herman Deleeck Centre for Social Policy

University of Antwerp

Sint-Jacobstraat 2

2000 Antwerp

Belgium

E-mail: ive.marx@ua.ac.be 


\section{Introduction}

Relative income poverty affects 5 to 15 per cent or more of Europeans whose main activity is paid work. It also affects their families; the majority of children growing up in financial poverty live in a household with at least one earner (Van Mechelen and Bradshaw, 2012). A long-standing issue in the United States, concern about in-work poverty is now also mounting in Europe. The past few years have seen a rapid rise in the number of academic publications dealing with in-work poverty within the European context (Marx and Verbist, 1998; Nolan and Marx, 2000; Andre $\beta$ and Lohmann, 2008; Lohmann, 2009; Crettaz, 2011; Fraser et al., 2011; Maitre et al., 2011; Kenworthy, 2011; Marx and Nolan, 2012; Van Lancker, 2012) ${ }^{1}$. Some see far reaching societal implications (Standing, 2011). At the policy level, too, a growing awareness is evident. In its 2011 report on 'Employment and Social Developments in Europe', the European Commission states: 'Although it is clear that, while employment is the most important factor in preventing poverty, it is also true that the phenomenon of monetary in-work poverty is nonetheless all too real'.

This recognition is certainly important given that policy efforts at the EU level and also in many countries have become strongly focused on increasing the number of workers and reducing the number of people reliant on transfers. Boosting employment levels was at the heart of the Lisbon Agenda (Cantillon, 2011; Vandenbroucke and Vleminckx, 2011). The ambitious Europe 2020 employment targets show this drive to be undiminished (Marlier et al., 2010). Further increases in labour force participation will involve drawing into the labour market those with weaker education and work history profiles. Projections indicate that further increases in employment are unlikely in themselves to reduce relative poverty, given current institutional settings and supports (Marx et al., 2012a).

In this context it is clearly relevant to look more closely at the institutions and provisions that help to ensure minimum income protection to workers. Minimum wages, as imposed by law or through collective bargaining, constitute an important pillar of direct minimum income protection for workers. Historically, ensuring 'fair wages' has been as important an objective but in this paper we consider minimum wages mainly from the perspective of their role in ensuring minimally acceptable living standards to people solely or mainly reliant on earnings.

When one is interested in net disposable incomes of workers at the lowest end of the income distribution it is not enough to look only at gross minimum wage levels and trends, the usual focus in the extensive labour economics literature on this subject (Card and Krueger, 1994; Freeman, 1996; Dolado et al., 2000; OECD, 1998, 2004; Neumark and Wascher, 2007; Boeri, 2012). One also needs to take into account the impact of taxes, social security contributions and possible benefits on the disposable incomes of minimum wage workers. In this paper, we assess the level of these minimum income packages against the poverty threshold. In addition, we consider trends over the last decade, both in the overall packages and in the constituent components. A final section of this paper is devoted to a discussion of whether and how minimum income protection for workers could be improved.

\footnotetext{
${ }^{1}$ For a global perspective see Fields, 2011
} 


\section{Context: low pay and in-work poverty}

This section briefly covers two key contextual issues. First, is there evidence that earnings and living standards of European workers are under pressure and, second, is there evidence that, as a possible consequence, in-work poverty is (potentially) on the increase?

\subsection{Are wages under pressure?}

While higher educated workers appear to be benefiting from economic globalization and technological advances, less skilled workers are seen to be losing out, especially in richer countries, where they are comparatively costly. Research by labour economists shows that this picture of a uniform shift away from low skilled work needs nuance (Autor et al., 2003; Goos et al., 2009). Studies show that there is growth in employment in both the highestskilled (professional and managerial) and lowest-skilled occupations (non-exportable personal services), with declining employment in the middle of the distribution (manufacturing and routine office jobs).

Turning to the supply side, an increased policy emphasis on increasing effective labour market participation has become evident in many European countries, certainly at the level of rhetoric, and gauging by some indicators also in terms of actual policy (Barbier and LudwigMayerhofer, 2004; Kenworthy, 2008; Weishaupt, 2012). Within the broad set of activation strategies deployed, an important number specifically target the long-term unemployed, including social assistance recipients. Some measures specifically aim to stimulate people to accept relatively low-paid/minimum wage level jobs. In the case of Belgium, for example, the main activation measure for social assistance recipients is a public employment scheme offering minimum wage level jobs. There are other countries where similar subsidized or publicly financed jobs exist (OECD, 2007). Employment subsidies and employers' social security contribution reductions also generally aim to stimulate the creation and take-up of relatively low-paid, or at least minimum-wage level, jobs.

The OECD's low pay database, the most widely-cited source of comparative data on the extent of low pay, shows the proportion of low-wage workers in rich countries ranging from around one in twenty in Sweden to around one in four in the United States (OECD, 2006). Although a clear demarcation is often assumed to exist between the Anglo-Saxon countries and the Continental European the evidence does not support this. Nor is it the case that low-paid work has necessarily increased most in the less regulated, more service-intensive economies: it has remained relatively steady (at a high level) in the US, and though increasing in the UK this was proportionally by not much more than for example in the Netherlands (Lucifora and Salverda, 2008). In fact, the OECD database suggests that the largest increases in low pay (for full-time workers) have taken place in countries like Denmark, Germany and Poland.

There is as yet also no systematic research available linking low pay trends with the intensity of activation efforts, in part because actual activation intensity is so difficult to quantify. In the case of the Netherlands, where activation efforts have been fierce, there is evidence of an increase in low-paid work (Salverda et al., 2008). In the German case, drastic labour market and social security reform has coincided with a rise in low-paid work (Bosch and Weinkopf, 2008; Kenworthy, 2011). 


\subsection{Is in-work poverty on the increase?}

According to Eurostat figures, which are drawn from EU SILC, the extent of in-work poverty in EU member states ranges from a low of four to five per cent to upwards of 15 per cent. The definition used here is one based on individual employment status (in work for most of the year) and household income situation adjusted for household size and composition. Persons "at risk of poverty" live in households with a disposable income below 60 per cent of the median income in their own country.

Eurostat figures also suggest that in the period 2000 to 2009, in-work poverty increased by more than one percentage point in Denmark, Germany, Spain, Romania, Sweden and the UK, but fell in as many countries. Thus there is no evidence of an overall increase over that period. Steady poverty risks for workers in the context of rising employment rates do however imply an increase in the number of working persons in poverty. There is also a significant overlap with child poverty (see Van Mechelen and Bradshaw, 2012).

When thinking about minimum income protection for workers it is essential to understand how low-paid work and in-work poverty interrelate. Various studies have demonstrated that the overlap between low pay and poverty is weak - in the order of five to ten per cent in most industrialized economies (Marx and Nolan, forthcoming 2012). This is because poor households generally do not contain an employee, whether low-paid or not, while most low-paid workers live in households with more than one earner. A crucial influence is thus the extent to which the household relies on the earnings of this low-paid worker. Particularly for low-paid women and young people, their earnings most often constitute a secondary or even tertiary source of income for the household. In some cases, accepting a low-paid job helps to lift household income above the poverty threshold (Gardiner and Millar, 2006). Low-paid workers who are not primary earners are often reasonably high up the household income distribution.

Households that are classified as working poor generally rely on comparatively low earnings, though not necessarily below conventional low pay thresholds. The core of the working poor consists of workers who are sole earners - generally with a low earned income - and have a family to support. Even a job paid well above the minimum wage may not suffice to meet household income needs, depending on the extent of those needs and the other sources of income available to the household.

What matters is the combined labour market position of household members. Having only one earner in the household has become a poverty risk in an era in which the average living standard, and hence the relative poverty threshold, is increasingly determined by the dual earner living standard. This helps to explain why in-work poverty is pervasive across Europe, and why its extent does not simply reflect the size of the low-wage sector. In-work poverty is thus a problem associated with a variety of institutional factors (e.g. labour market regulation, child care support, tax incentives etc.) that influence a household's capacity for acquiring multiple incomes in an era in which multiple household incomes are usually required to attain a decent standard of living (Lohmann and Marx, 2008; Lohmann, 2009; Crettaz, 2011).

\section{Data and analytical approach}

The next sections will look at minimum income protection levels for workers in Europe and three US States, Nebraska, New Jersey and Texas. It is particularly useful to include the United States in the comparison because in-work poverty is a long-standing policy concern

there. The focus is on the adequacy, from a poverty prevention perspective, of net income packages at minimum wages. The analysis is based on model family simulations of net 
disposable incomes of one-earner families with the earner working for the minimum wage, if applicable. These household types are mainly different in terms of their composition: the number of adults living in the household, the number of children and their age. The data draw on the CSB-MIPI dataset (Cantillon et al., 2004; Van Mechelen et al., 2011). Net disposable income consists, following the OECD (2002) definition, of the sum of the principal income component (that is, gross minimum wage) plus child cash benefits and housing allowances, minus income taxes, social security contributions and local taxes. Unlike the OECD, housing allowances are only taken into account insofar they are not discretionary awarded. Where these exist, negative income taxes are taken into account. In some countries, these negative income taxes are conditional upon work or are designed to support families with children, or both. We have tried, to the extent possible, to distinguish between income tax credits that are work related (that are to be found under income taxes) and those that are solely aimed at families with children (that are classified under child cash benefits). Moreover, for net disposable income at the minimum wage, social assistance top-ups turn out to be relevant for a number of countries.

The analysis proceeds by presenting first the different minimum wage schemes applicable in the countries of our sample. We then compare gross minimum wage levels across countries, relative to average wages and living standards. Next, we analyze how net disposable income packages at minimum wage level compare to relative poverty thresholds. Finally, we consider net income trends over the past decade, including trends in the constituent components.

\section{$4 \quad$ Minimum wages and institutionally imposed wage floors}

Minimum wages are not just, or for that matter even principally, about minimum income protection. Other considerations matter, not least (perceived) fairness, inequality and the desire to maintain adequate work incentives for those outside the labour market (International Labour Organization, 2008). Here, however, we are interested in whether minimum wage earners succeed in living a life free from severe financial hardship. This concern is also voiced by the EU, when calling for decent wages. Another perceived function of minimum wages is that when subsidies are directed towards low wage earners, that these will not be pocketed by employers or lead to wage erosion (European Commission, 2010; Immervoll, 2007).

The large majority of European countries have a national minimum wage (see Table 1), set by law or through collective bargaining at the national level (Vaughan-Whitehead, 2010; Boeri 2012). The early 1990s saw the introduction of minimum wages in the formerly Communist countries that are now part of the European Union. The United Kingdom introduced a national minimum wage in 1999 and Ireland one year later. Recent developments in Austria definitely point towards an introduction of a national minimum wage, since an agreement between the trade unions and the employers became applicable as of January 2009, establishing a minimum wage covering almost the entire private sector. ${ }^{2}$ In Germany, the minimum wage is again at the centre of the political debate.

In 2010, twenty Member States of the European Union had a national minimum wage, set by government, often in cooperation with or on the advice of the social partners, or by the social partners themselves in a national agreement. The federal minimum wage in the United States is determined by the federal government. The states can set higher minimum wages. Of the

\footnotetext{
${ }^{2}$ The resulting drop in private sector employees earning less than the agreed wage level of 1000 euro per month was considerable, from at least 20000 employees to a few hundred (European Commission, 2010).
} 
three states in our sample (Nebraska, New Jersey and Texas) only New Jersey exercised this right for a limited period (2005-2008) during the past decade. Table 1 presents an overview of the minimum wages assessed in this paper, and the estimated share of the labour force working at this minimum wage. The methodology behind these estimates differs considerably between the countries included; known caveats of the estimates are mentioned in the footnotes under the table.

Notwithstanding these reservations, it seems that the prevalence of minimum wage workers varies greatly between the countries in our sample, though no clear patterns are apparent. In some countries the primary purpose of the "headline" minimum wage is to act as a benchmark: it marks the floor of the wage hierarchy. "Real" minimum wages (i.e. pay scales for the youngest, least qualified and least experienced workers as stipulated in collective agreements) are sometimes considerably higher than the nationwide minimum wage as sectoral negotiations may overbid the national minimum wage. In other countries, like Greece or France, it appears that more workers work effectively for the minimum wage

There are few countries without a minimum wage. In Germany, Cyprus, Denmark, Finland, Italy, Norway and Sweden, workers are at most covered by sectorally applicable minimum wages. Although the proportion of covered employees can be quite large, considerable differences in minimum wages between various sectors or regions may exist (for instance, see database on sectoral minimum wages in Germany of the Wirtschafts- und Sozialwissenschaftliche Institut (2011)) (Immervoll, 2007). Therefore, we tried to gather information on a sectoral minimum wage in one of the countries' low wage sectors. For Italy, the national respondent provided us with information on the minimum wage agreed between the social partners for a blue collar worker with the lowest qualification level in the low-paid leather and fur sector. ${ }^{3}$ Unfortunately, it was not possible to consistently gather information on low minimum wages for the other countries lacking a national minimum wage. We include Austria in our assessment for 2009, since the newly agreed minimum wage approaches a quasi-statutory minimum wage.

In the remainder of this paper we focus on minimum wages in all countries mentioned in Table 1, except for Malta and Cyprus, due to a lack of data, the Scandinavian countries (NO, SE, FI, DK) and Germany, due to a lack of data with respect to an alternative for an official minimum wage.

\footnotetext{
${ }^{3}$ Although we consider this approach to be the most valid when trying to compare the wage floor in the various European countries, some reservations apply. For one thing, we cannot be sure that this will indeed be the lowest minimum wage applicable in Italy. However, large differences are unlikely. More serious is the fact that when collective bargaining coverage declines, unregulated parts of the labour market may become more common (ILO, 2008).
} 
Table 1. Overview of minimum wage schemes in EU 27, plus Norway and three US states

\begin{tabular}{|c|c|c|c|}
\hline Country & Minimum wage & $\begin{array}{l}\text { \% of working } \\
\text { population } \\
\text { (employees) }\end{array}$ & Minimum wage setting (ICTWSS database of Visser, 2011) \\
\hline AT & Mindestlohn & $\mathrm{n} / \mathrm{a}$ & National agreement between unions and employers \\
\hline $\mathrm{BE}$ & $\begin{array}{l}\text { Gewaarborgd Minimum } \\
\text { Maandinkomen }\end{array}$ & $3,65 \%^{\mathrm{a}}$ & $\begin{array}{l}\text { by agreement, but extended and made binding by law or } \\
\text { ministerial decree }\end{array}$ \\
\hline BG & минимална работна заплата & $\mathrm{n} / \mathrm{a}$ & by government after non-binding tripartite consultations \\
\hline $\mathrm{CY}$ & $\begin{array}{l}\text { None } \\
\text { (in some sectors only) }\end{array}$ & & by government, bound by fixed rule \\
\hline $\mathrm{CZ}$ & Minimální mzda & $2.5 \%$ & by government, no fixed rule \\
\hline DK & None. & & $\begin{array}{l}\text { (sectoral) collective agreements or tripartite wage boards in } \\
\text { some sectors }\end{array}$ \\
\hline $\mathrm{EE}$ & Riiklik alampalk & $\begin{array}{l}4.6 \% \text { of full-time } \\
\text { employees }{ }^{\mathrm{b}}\end{array}$ & $\begin{array}{l}\text { by agreement, but extended and made binding by law or } \\
\text { ministerial decree }\end{array}$ \\
\hline ES & Salario Mínimo Interprofesional & $2.6 \%^{\mathrm{c}}$ & by government after non-binding tripartite consultations \\
\hline FI & None. & & $\begin{array}{l}\text { sectoral collective agreements of tripartite wage boards in } \\
\text { some sectors }\end{array}$ \\
\hline FR & $\begin{array}{l}\text { Salaire minimum interprofessionnel } \\
\text { de croissance }\end{array}$ & $10.6 \%{ }^{\mathrm{d}}$ & by government, without fixed rule \\
\hline GR & $\begin{array}{l}\text { Quasi statutory minimum wage, } \\
\text { name: } \text { n.a. }\end{array}$ & $20.4 \%^{\mathrm{e}}$ & by government, bound by fixed rule \\
\hline $\mathrm{HU}$ & $\begin{array}{l}\text { Teljes munkaidõben foglalkoztatottak } \\
\text { minimálbére }\end{array}$ & $2.7-2.8 \%{ }^{\mathrm{f}}$ & through tripartite negotiations \\
\hline IE & National Minimum Wage & $\mathrm{n} / \mathrm{a}$ & by judges or experts committee \\
\hline IT & $\begin{array}{l}\text { None } \\
\rightarrow \text { here: minimum wage applicable in } \\
\text { low-paid leather and fur sector }\end{array}$ & & $\begin{array}{l}\text { sectoral collective agreements or tripartite wage boards in } \\
\text { some sectors }\end{array}$ \\
\hline LT & Minimali mënesinë alga & $6.98 \%{ }^{\mathrm{h}}$ & by government after non-binding tripartite consultations \\
\hline LU & Salaire Social Minimum ${ }^{\mathrm{g}}$ & $11.2 \%{ }^{\mathrm{i}}$ & by government, bound by fixed rule \\
\hline LV & Minimālā mēneša darba alga & $18 \%{ }^{\mathrm{j}}$ & by government, without fixed rule \\
\hline MT & Statutory minimum wage, name: n.a. & n.a. & by government, bound by fixed rule \\
\hline NL & Wettelijk minimumloon & $1.6 \%{ }^{\mathrm{k}}$ & by government, bound by fixed rule \\
\hline NO & None. & & $\begin{array}{l}\text { (sectoral) collective agreements or tripartite wage boards in } \\
\text { some sectors }\end{array}$ \\
\hline PL & Placa minimalna & $2 \%^{1}$ & by government after non-binding tripartite consultations \\
\hline PT & $\begin{array}{l}\text { Retribuição Mínima Mensal Garantida } \\
\text { (RMMG) }\end{array}$ & $\begin{array}{l}8,7 \% \text { of full-time }^{\mathrm{m}} \\
\text { employees }^{\mathrm{m}}\end{array}$ & by government, without fixed rule \\
\hline RO & Salariul minim pe economie & $\mathrm{n} / \mathrm{a}$ & by government after non-binding tripartite consultations \\
\hline SE & None. & & $\begin{array}{l}\text { (sectoral) collective agreements or tripartite wage boards in } \\
\text { some sectors }\end{array}$ \\
\hline SI & minimalna plaèa & $2.8 \%{ }^{\mathrm{n}}$ & by government, bound by fixed rule \\
\hline SK & minimálna mzda & $\mathrm{n} / \mathrm{a}$ & by government, without fixed rule \\
\hline UK & National minimum wage & $4.3 \%^{\circ}$ & by judges or experts committee \\
\hline US & Minimum wage & $\begin{array}{l}4.9 \% \text { overall; } 8.5 \\
\% \text { for Texas; } 5.8 \\
\text { for New Jersey } \\
\text { and Nebraska }^{p}\end{array}$ & by government, without fixed rule \\
\hline
\end{tabular}

Note: Figures are not fully comparable. ${ }^{a}$ EU-SILC 2004 estimate; ${ }^{\mathrm{b}} 2006$ : \% of full-time employees that receives wages less than or equal to minimum wage (interval EEK 2500-3000, minimum wage in 2006: 3000 EEK); ${ }^{c}$ No official data; ${ }^{\mathrm{d}}$ Data based on DARES, a survey excluding employees in agriculture, in public administrations, in interim enterprises, in associations working in the sector of social action and in family employment; ${ }^{\mathrm{e}}$ Rough estimate based on LFS 2007 (\% of working population earning between $€ 500$ and $€ 750$, minimum wage in 2007: $€ 658) ;{ }^{\mathrm{f}} 2008 ;{ }^{\mathrm{g}}$ Percentage refers to all employees working for a wage around a minimum wage (both qualified and non-qualified workers). The percentage for non-qualified workers is $6.2 \% ;{ }^{\mathrm{h}} 2007 ;{ }^{\mathrm{i}}$ March 2008, statistics based on the number of persons paid around the minimum wage. Statistics refer to private sector only, resident workers and cross-border workers; ${ }^{j}$ Second quarter of 2009. Minimum (and below) wage earners; ${ }^{\mathrm{k}} 2006 ;{ }^{1}{ }^{2} 2007$, percentage based on official data of Ministry of Labour and Social Policy, contested by trade unions; ${ }^{\mathrm{m}}$ October 2009; ${ }^{\mathrm{n}}$ February 2009; ${ }^{\mathrm{C}}$ April 2008 (earning minimum wage or less); 2009 annual averages.

Source: CSB-MIPI (Van Mechelen et al., 2011, p. 10); (Visser, 2011). 
Minimum wage levels differ considerably across the set of countries we consider. Figure 1 presents the minimum wage level applicable for a 35-year old worker, as do all figures and tables in this paper. ${ }^{4}$ For some countries this means that we present a somewhat higher minimum wage than the one commonly used, and this is due to experience-related upgrades. As can be seen from Figure 1, minimum wage levels range in 2009 from around 30 per cent of gross male average wage in the Czech Republic, Estonia and the United Kingdom to a maximum of over 45 per cent in Belgium and Greece. In PPS the range is understandably even wider, with minimum wages in the more generous countries exceeding those in the least generous countries by a factor of six. Note that the newest EU member states generally have national minimum wages that are among the least generous when considering purchasing power standards. Relative to average wages, however, minimum wages there are not particularly low. Likewise, Portugal and Greece have minimum wages in the middle of the distribution in terms of PPS, but relative to average male wages these countries have among the most generous minimum wages.

Figure 1. Gross monthly minimum wage levels in 2009, PPS, euro and relative to average wages.

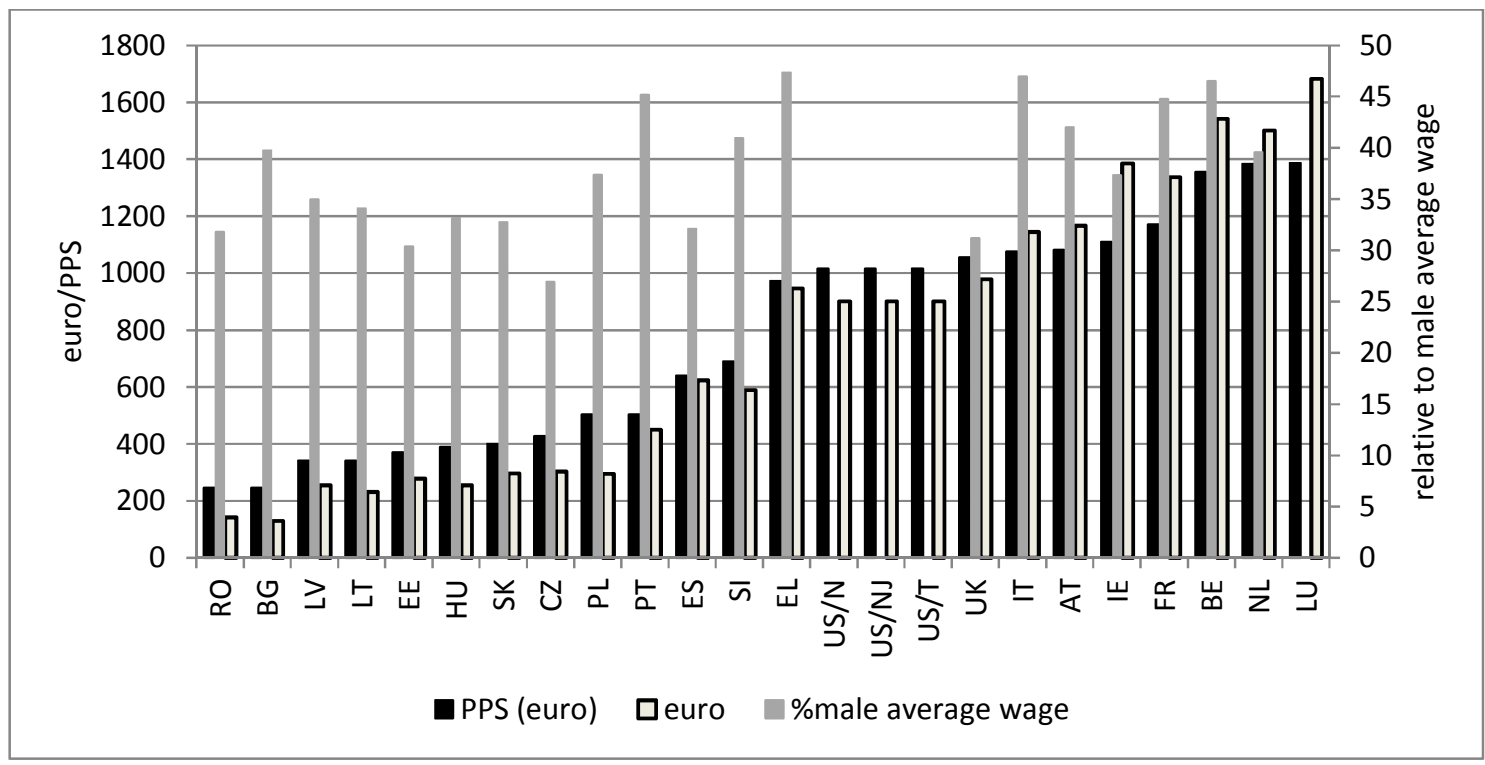

Note: Gross average wages for a 35-year old male worker. Gross minimum wages for a 35-year old worker. For some countries (BG, EL) this differs with commonly presented minimum wage levels, due to experience premiums. No gross male average wage available for LU and the US states.

Source: CSB-MIPI (Van Mechelen et al., 2011)

\section{Net incomes at minimum wage level relative to the poverty threshold}

We now turn to the main focus of attention, the level of net disposable incomes at minimum wage relative to the poverty threshold.

Figures 2 and 3 present the net disposable income of a single person household and a family with two children, with the earner working at the minimum wage. For a single person household, net disposable income suffices in about half the countries of our sample to avoid

\footnotetext{
${ }^{4}$ Likewise, gross average wages refer to the average wage for a 35 -year old male worker.
} 
the risk of being poor. Note, however, that gross minimum wages are above or very near to the national at-risk-of-poverty threshold in all but a few countries ${ }^{5}$. It is taxes and social security contributions which cause net disposable income at the minimum wage to be below the poverty threshold in a significant number of countries. Some countries, for instance the Czech Republic, Spain and the Slovak Republic, levy no income taxes on the income of minimum wage earners. The UK awards an income tax credit, but the impact of this measure is dampened by high local taxes. Other countries awarding income tax credits to minimum wage earners are Austria and France. In two countries, the Netherlands and Belgium, income taxes for single persons earning a minimum wage remain substantial. However, social security contributions are limited in these cases.

Figure 2. Breakdown of net disposable income of a single minimum wage earner, 2009, relative to the $60 \%$ at-risk-of-poverty threshold.

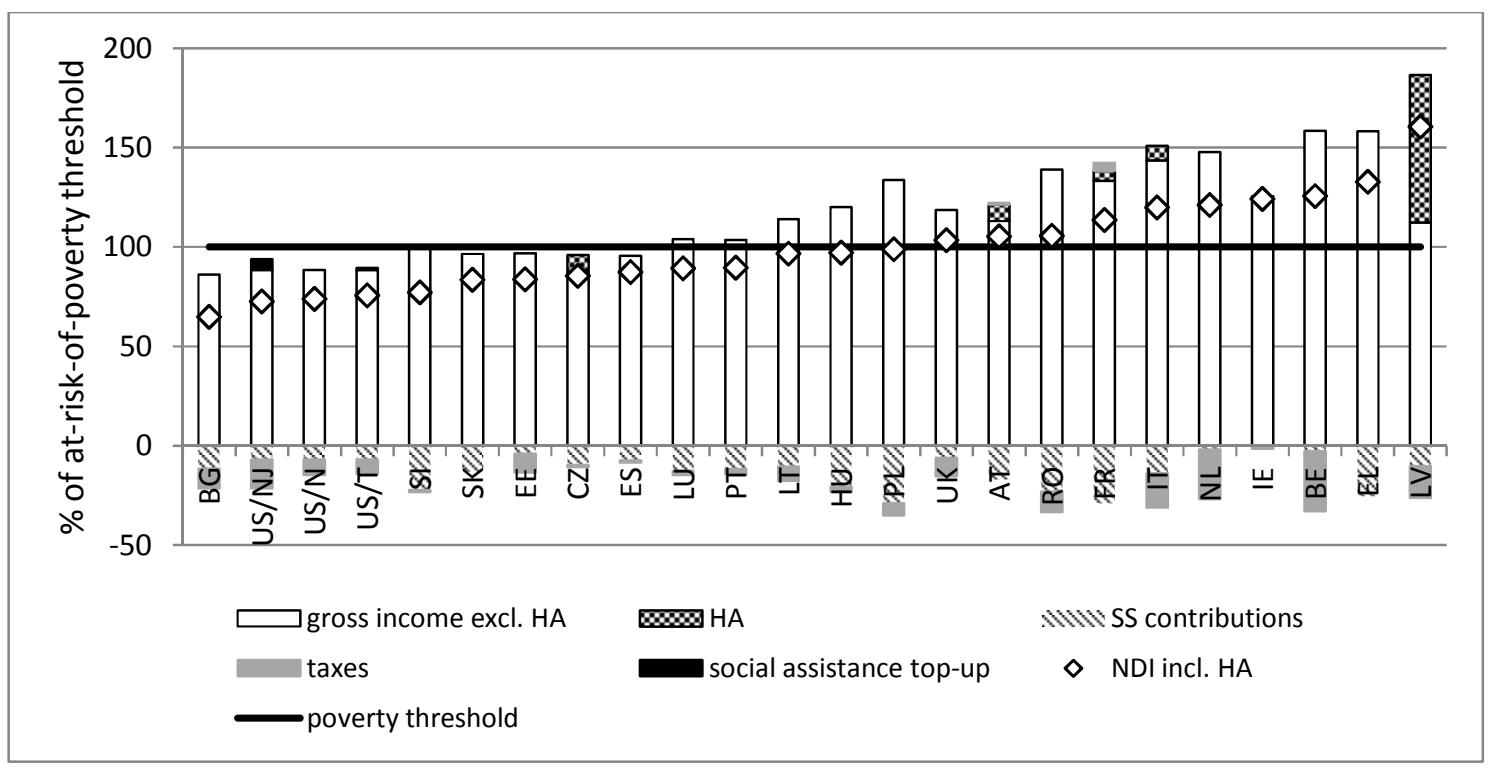

Note: HA: housing allowance, NDI: net disposable income, SS: social security; taxes: sum of income tax and local taxes. AT and IT: no genuine statutory MW. For a discussion, see section 4.

Source: CSB-MIPI (Van Mechelen et al., 2011); Poverty thresholds retrieved from Eurostat (2011), U.S. Bureau of the Census and Bureau of Labour Statistics (2011)

\footnotetext{
${ }^{5}$ The at-risk-of-poverty threshold used throughout this paper is the official EU monetary at-risk-of-poverty threshold, defined as $60 \%$ of median equivalent household income in each country (after taxes and transfers, modified OECD equivalence scale). This relative poverty threshold differs substantially from the official US poverty threshold, which entails a more absolute approach. Official US poverty thresholds are based on a calculation of the costs of the food budget, multiplied by a certain factor to account for non-food expenses. The official US poverty thresholds, that vary by household size, were established in the 1960s and have since then been regularly adjusted to inflation. Given large differences both in the underlying concept of poverty as in the methodology, the $60 \%$ at-risk-of-poverty threshold for the US is considerable higher than the official US poverty threshold (for a single person: $\$ 17035$ as compared to $\$ 11161$ dollar in 2009). It should however be noted that the official US poverty threshold is compared to before tax income, excluding near cash benefits such as food stamps, whereas the EU at-risk-of-poverty threshold takes account of net income, after taxes and transfers. The poverty thresholds therefore cannot be simply compared. For more information on the impact of the different poverty definitions and income concepts on poverty rates, see Notten and de Neubourg (2011).
} 
Single minimum wage earners rarely receive additional allowances. Only Latvia, Italy, France, Austria and the Czech Republic award housing allowances to single minimum wage earners. There is no European country providing social assistance top-ups to single minimum wage earners. Compared to social assistance recipients, single minimum wage earners are relatively well off, even when not reaching the at-risk-of-poverty threshold (see Van Mechelen and Marchal, 2012). Two of the three US states in our sample, New Jersey and Texas, do provide a small top-up, under the Supplemental Nutritional Assistance Program (SNAP, commonly referred to as food stamps). This program provides a debit card to eligible households which can be used to purchase specific goods in participating food retailers. However, take-up rate of this top-up is rather low among the working poor (United States Department of agriculture, food and nutrition services, 2010). In Figures 2, 3 and 4, the money value of this debit card is included.

Figure 3. Breakdown of net disposable income of a one-earner family with two children at minimum wage, 2009 , relative to the $60 \%$ at-risk-of-poverty threshold.

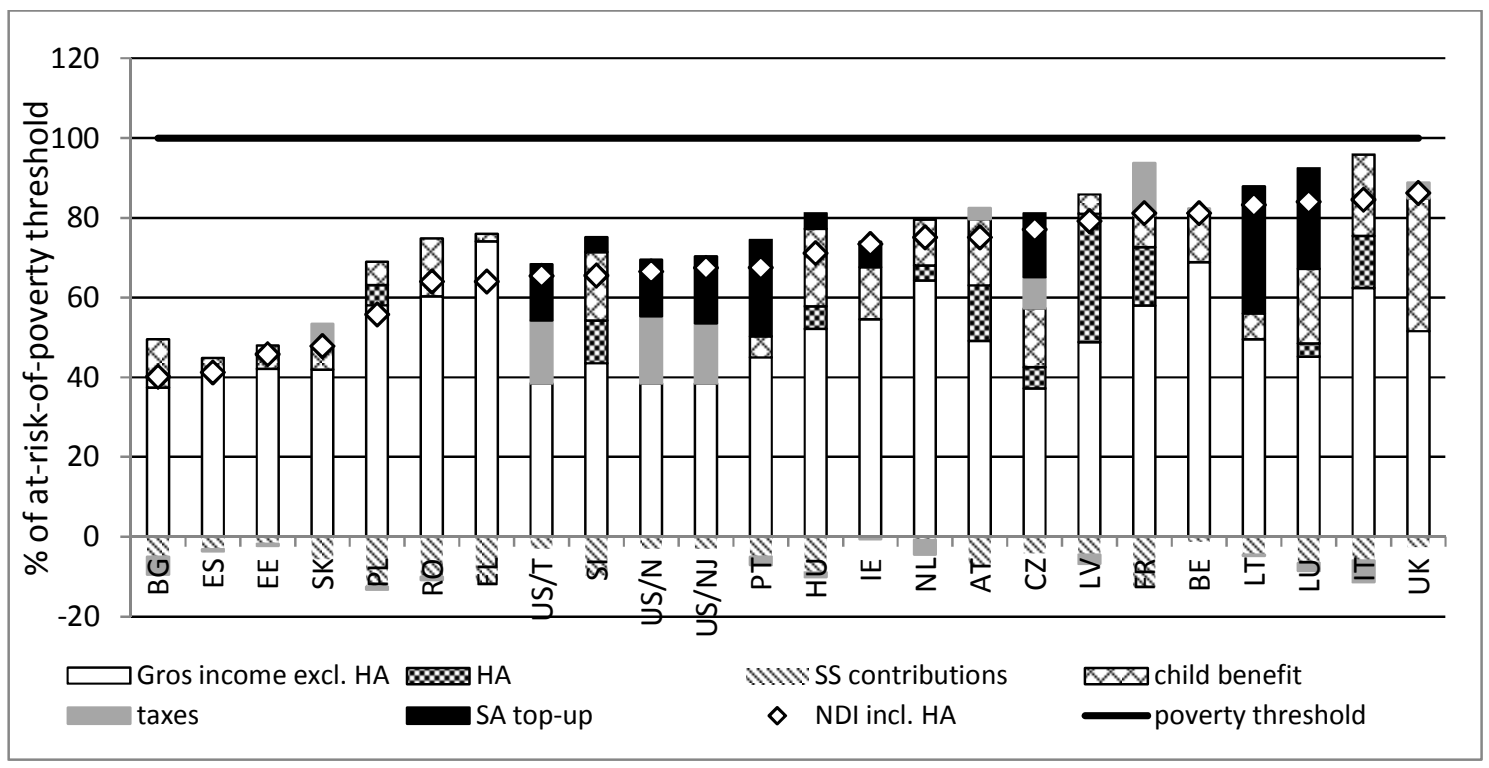

Note: For comparability reasons heating allowance is excluded from the simulations (BG and HU). The social assistance top-up in Poland is not always awarded. HA: housing allowance, NDI: net disposable income, SS: social security; taxes: sum of income tax and local taxes. AT and IT: no genuine statutory MW. For a discussion, see section 4 .

Source: CSB-MIPI (Van Mechelen et al., 2011); Poverty thresholds retrieved from Eurostat (2011), U.S. Bureau of the Census and Bureau of Labour Statistics (2011).

The situation is different when there are dependents, especially children, present in the household. Figure 3 shows the net disposable income and its components relative to the 60 per cent at-risk-of-poverty threshold for a sole breadwinner couple with two children. Strikingly, a family in this situation does not escape poverty in any country. In fact, the gap between their income and the poverty threshold is quite substantial in most countries, indicating that even a wage substantially above the minimum wage would not suffice. Yet in many countries child cash benefits are quite substantial, most notably in the UK. Likewise, families with children often receive income top-ups, such as the family income supplement in Ireland, regular social assistance top-ups in Lithuania, Luxembourg and the Czech Republic and SNAP benefits in the US states. Also, families in the situation simulated here can apply 
for housing allowances in a considerable number of countries. Moreover, following the design of most tax systems, wherein generally tax allowances are granted for dependent household members, income taxes very nearly disappear in most countries, or become positive tax credits (Slovak Republic, Austria, Czech Republic, France, UK, US).

Figure 4 shows the income package of a lone parent with two children. In most countries, this family type does somewhat better than a couple with two children. In a small number of countries, a lone parent raising two children and working full time for the minimum wage has an income package just above or around the poverty threshold. This is mainly because lone parents receive the same (or almost the same) supportive measures as a couple with two children, while having the advantage of having one adult mouth less to feed. The effect, in other words, stems from the way the equivalence scale is calculated and not from more generous support. The few countries that provide additional measures towards lone parent families mainly do so by increased child benefits (like Belgium and Estonia) or by a more favorable tax treatment (as in the Netherlands). Note that the model family type calculation presented here assumes full time work. It goes without saying that many lone parents do not find it easy to combine a full time job with raising children. Minimum wage workers in particular are often employed in service sector jobs with non-standard work times, including weekend and night work. They face particular difficulties finding appropriate child care and actually working full time.

Figure 4. Breakdown of net disposable income of a lone parent with two children at minimum wage, 2009 , relative to the $60 \%$ at-risk-of-poverty threshold.

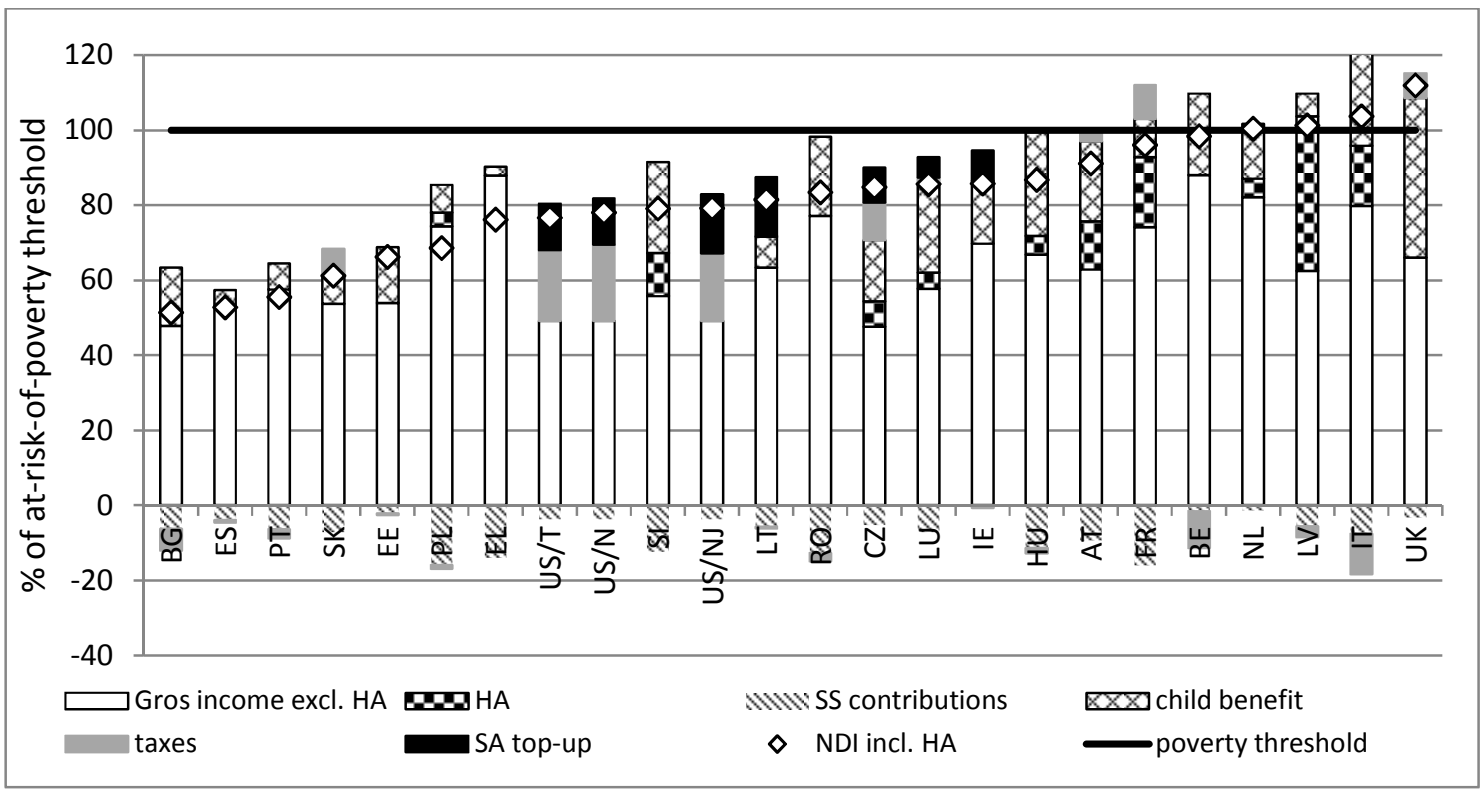

Note: For comparability reasons heating allowance is excluded from the simulations (BG and HU). HA: housing allowance, NDI: net disposable income, SS: social security; taxes: sum of income tax and local taxes. No comparable poverty threshold available for the US. AT and IT: no genuine statutory MW. For a discussion, see section 4.

Source: CSB-MIPI (Van Mechelen et al., 2011); Poverty thresholds retrieved from Eurostat (2011), U.S. Bureau of the Census and Bureau of Labour Statistics (2011). 


\section{Trends over the past decade}

Let us now turn to trends over the past decade, the period 2001-2009 to be more precise. Figure 5 shows trends in gross minimum wages and net income packages at minimum wages relative to median equivalent income and thus to relative poverty thresholds. Clearly, the scale of variation in trends is considerable, across countries but also across family types within countries. Note also that this picture is to some extent influenced - if not distorted - by the economic crisis which caused median household income to drop significantly in a number of countries. Had we presented the trend up until 2008, the overall picture would have been one of general decline.

Interestingly, in most countries net incomes at minimum wage increased more strongly, or declined less sharply than gross minimum wages, be it again with significant variation by family type. In Lithuania, for example, the level of the gross minimum wage declined relative to the poverty threshold yet net incomes for minimum wage earners improved, especially for those with dependent children. In France, to take another example, the gross minimum wage fell vis-à-vis the poverty threshold but this did not translate into a proportional drop in net incomes for minimum wage workers. Such divergent trends point to changes in the components that make up net disposable income. Thus we turn our attention to what happened with the various components.

Figure 5. Net disposable income trends for a one-earner family with the working adult earning a minimum wage relative to poverty thresholds, 2001-2009.

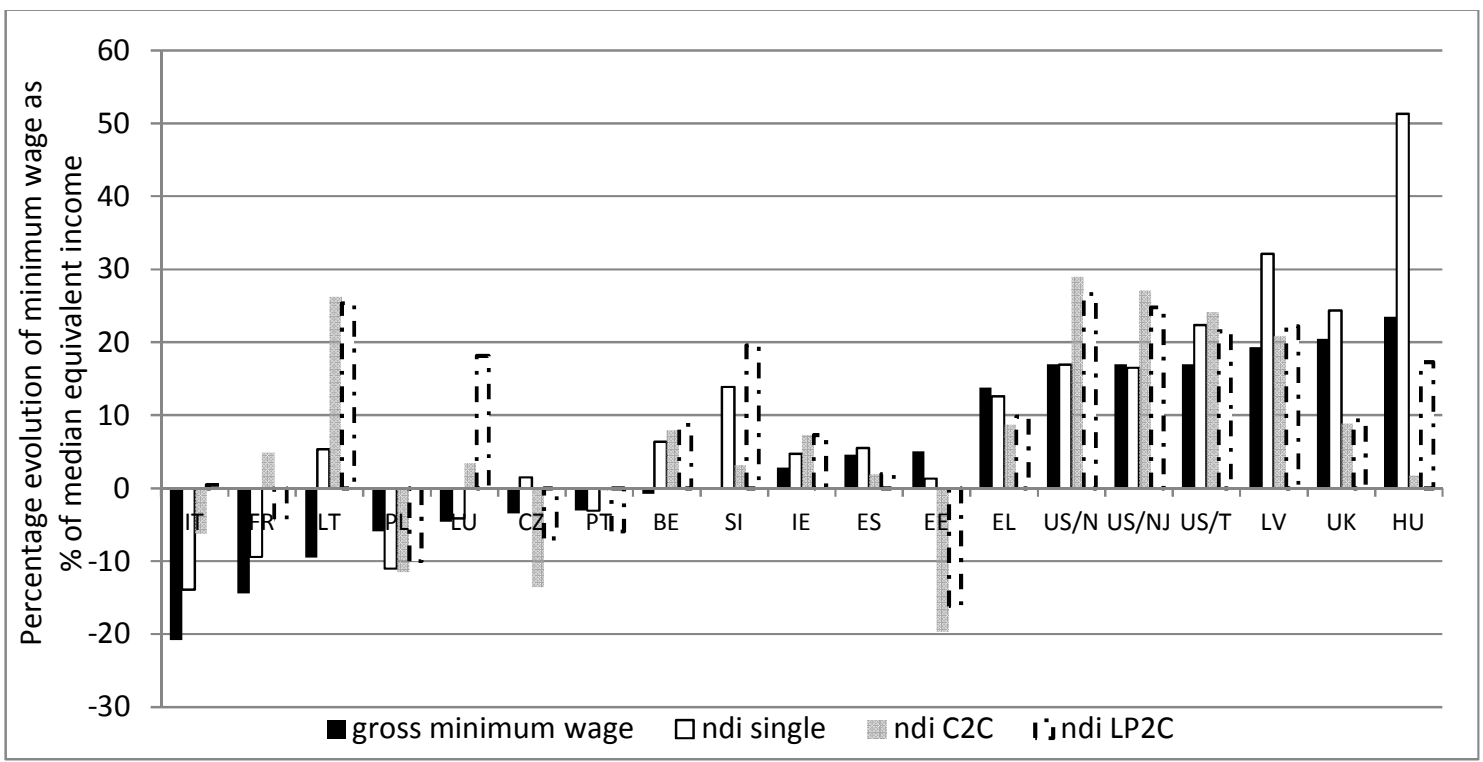

Note: NL not included due to break in series. No minimum wage in Austria in 2001. Housing allowances included if comparable over time. Countries are sorted by evolution of gross minimum wage over period. Ndi: net disposable income. C2C: couple with two children. LP2C: lone parent with two children.

Source: CSB-MIPI (Van Mechelen et al., 2011); Poverty thresholds retrieved from Eurostat (2011), U.S. Bureau of the Census and Bureau of Labour Statistics (2011) 


\subsection{Gross minimum wages}

In real terms, minimum wages increased in most EU countries in the period 2001-2009, especially in the EU12 countries. However, these real increases translate into a far more diverse picture relative to average earnings. From Figure 6, in which countries are ranked by their initial level in 2001, it can be seen that by and large the strongest increases occurred in the countries where the initial levels in 2001 were lowest. In the countries where they were highest in 2001, minimum wages generally declined relative to average wages. The figure also shows trends relative to relative poverty thresholds. Clearly the picture is more mixed. It is again important to stress that the overall picture would have been of declines had we compared 2001-2008, that is, before the crisis caused a drop in median equivalent incomes. It is also important to stress that this figure may suggest a continuity in trend that is not really there in fact. For example, in the United States, the minimum wage eroded, both in real terms as well as relative to gross average wages for the largest part of the decade before gross minimum wage levels were finally substantially raised again.

Figure 6. Gross minimum wage trends relative to gross average wage and median equivalent income, ranked by 2001 level relative to gross average wage.

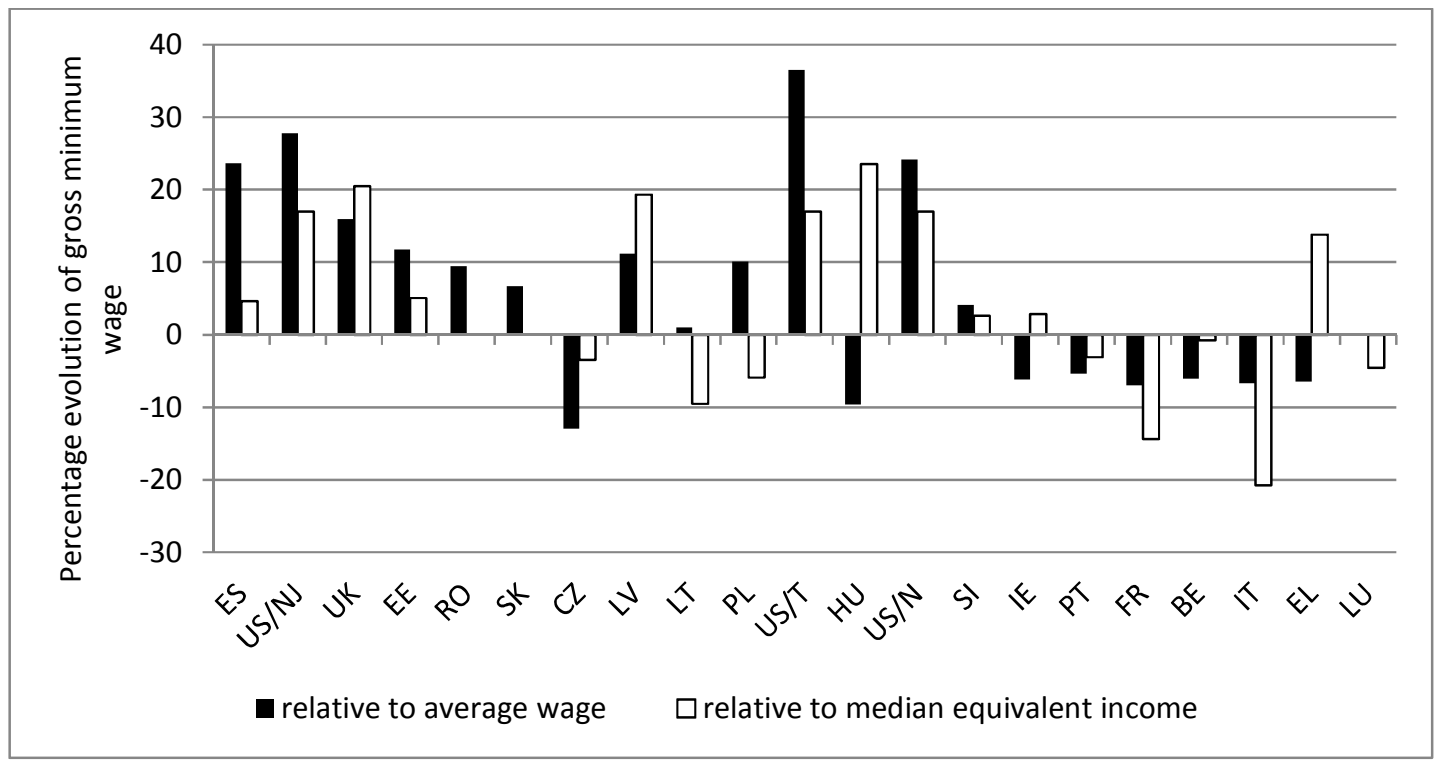

Note: NL not included due to break in series. No minimum wage in Austria in 2001. Housing allowances included if comparable over time.

Source: CSB-MIPI (Van Mechelen et al., 2011); Poverty thresholds retrieved from Eurostat (2011), U.S. Bureau of the Census and Bureau of Labour Statistics (2011).

\subsection{Income taxes}

We have seen that in most countries net incomes at minimum wage increased more strongly, or declined less sharply, than gross minimum wage levels, suggesting changes in the components that affect net disposable income. We first look at the impact of income taxation policy changes. The overall picture, presented in Figure 7, is one of declining taxation levels, where and for whom there was still room for such declines. That was generally only the case for single person households; single breadwinner households with dependent children already paid close to zero taxes in our base year, 2001. An exception is Belgium, where income taxes 
remained significant for single minimum wage earners. In a limited number of countries we see an effective shift towards negative taxation, i.e. towards single persons receiving income supplements through the tax system. Poland and Romania increased the income tax for a single person minimum wage earner, although only by a small amount and from a very low level.

Turning to couples and lone parents with two children, the first thing to note is that income taxes were in general already minimal or non-existent in 2001. A few observations stand out. The Czech Republic introduced a comparatively generous tax credit for families with children as part of its 2008 flat tax reform, but this measure did not suffice to keep net disposable income in line with the standard of living (see Figure 5). Lithuania, the only country with a relatively high income tax in 2001, has drastically cut back this tax. The personal income tax rate was substantially reduced (from 33 to 15 per cent) and the amount of the non-taxable income base was increased for low income families. In the Slovak Republic, the 2004 tax and welfare reform changed the existing child tax allowances into refundable tax credits. In France, the maximum value of the refundable Prime pour l'emploi (PPE, a working tax credit) was substantially raised between 2005 and 2008. From 2009 on, low-wage earners benefit from the newly introduced social assistance benefit $(\mathrm{rSa})$ that supports the working poor with a considerable top-up. Since the calculation of the PPE and the rSa interact, the net effect of both measures is included in Figure $7 .{ }^{6}$ For the UK, a reform of the working families' tax credit into the working tax credit and the child tax credit in April 2003 apparently had divergent consequences for different family types, with generosity declines for the two households types with dependent children presented here. ${ }^{7}$ Currently, the UK government is preparing a far-reaching reform of the benefit structure, including the tax credits, into a 'universal credit'. Striking also is the substantial impact, relatively speaking, of the Earned Income Tax Credit in the United States. This federal tax credit is the country's pre-eminent anti-poverty program for families of active working age. Although the EITC was expanded for families with three children or more in reaction to the crisis, the substantial increase in refundable tax credits observed for families with children in Figure 7 is due to two other crisis measures. The 2009 American Recovery and Reinvestment Act temporarily introduced the Making Work Pay tax credit, and issued a temporary expansion of the refundable Additional Child tax credit. ${ }^{8}$ The latter in particular had a substantial impact on the net disposable income of minimum wage earners with children.

\footnotetext{
${ }^{6}$ The PPE still exists, but is only partly cumulative with rSa. The activity-related part of the social assistance benefit is therefore taken into account when calculating the working tax credit.

${ }^{7}$ The reform also caused non-working families with children to receive the child tax credit

${ }^{8}$ The Making Work Pay Tax credit supported workers in 2009 and 2010. The refundable part of the Child Tax Credit is scheduled to return to its former levels after 2012.
} 
Figure 7. Trends in income taxes as percentage of gross minimum wage, 2001-2009

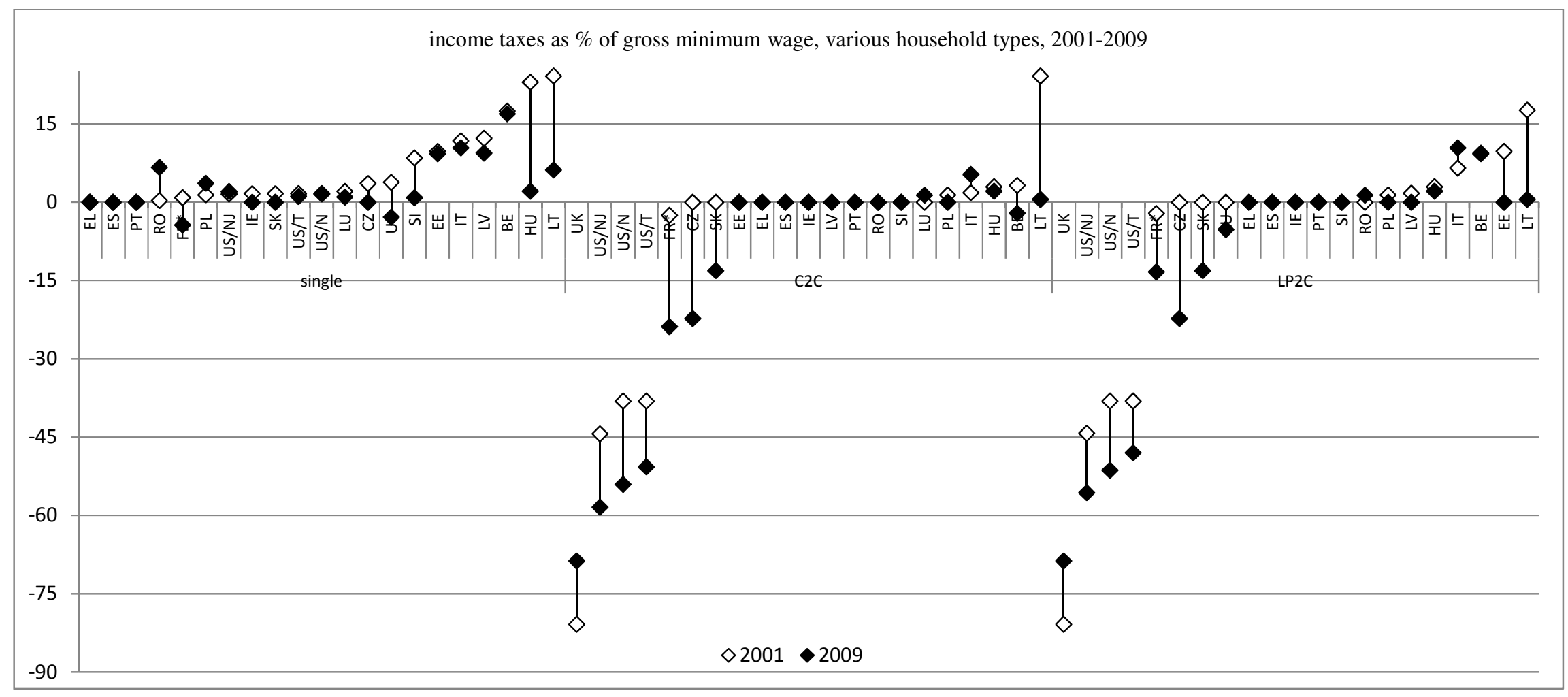

Note: C2C: couple with two children. LP2C: lone parent with two children. Within household types, countries are sorted by 2001 level. Gross minimum wage for a 35-year old worker. In case of couple with children, the worker is married. * France: includes working tax credit (Prime pour l'emploi) in 2001. This is (for the family types under consideration) supplemented by the rSa supplement in 2009 (here included under income tax). For Austria and Luxembourg, it was not possible to exclude a possible heating allowance.

Source: CSB-MIPI (Van Mechelen et al., 2011). 


\subsection{Social security contributions}

Social security contributions are levied on individual earnings and generally do not vary by family type. These continue to have a substantial impact on the net incomes of minimum wage workers, reducing net income by as much as a fifth in some countries. As can be seen from Figure 4, in a country like France a lone parent with two children working full time for the minimum wage would actually be above the poverty threshold if employee social security contributions were slightly lower. In the period under scrutiny here, social security contributions, while remaining substantial in most countries, decreased (marginally) in Poland, the Czech Republic, Romania and (more substantially) in Belgium. In the Belgian case, the prime objective was to increase work incentives, particularly the net pay-off to making the transition from dependence on a social assistance or unemployment benefit to a low-paid job. Since 2002, Estonian employees contribute to the unemployment insurance fund, as well as to the funded pension scheme. In Lithuania, social insurance contributions were raised from three per cent of gross wage income to nine per cent, of which three per cent for pension insurance and six per cent for health insurance.

Figure 8. Trends in social security contributions as percentage of gross minimum wage, 2001-2009.

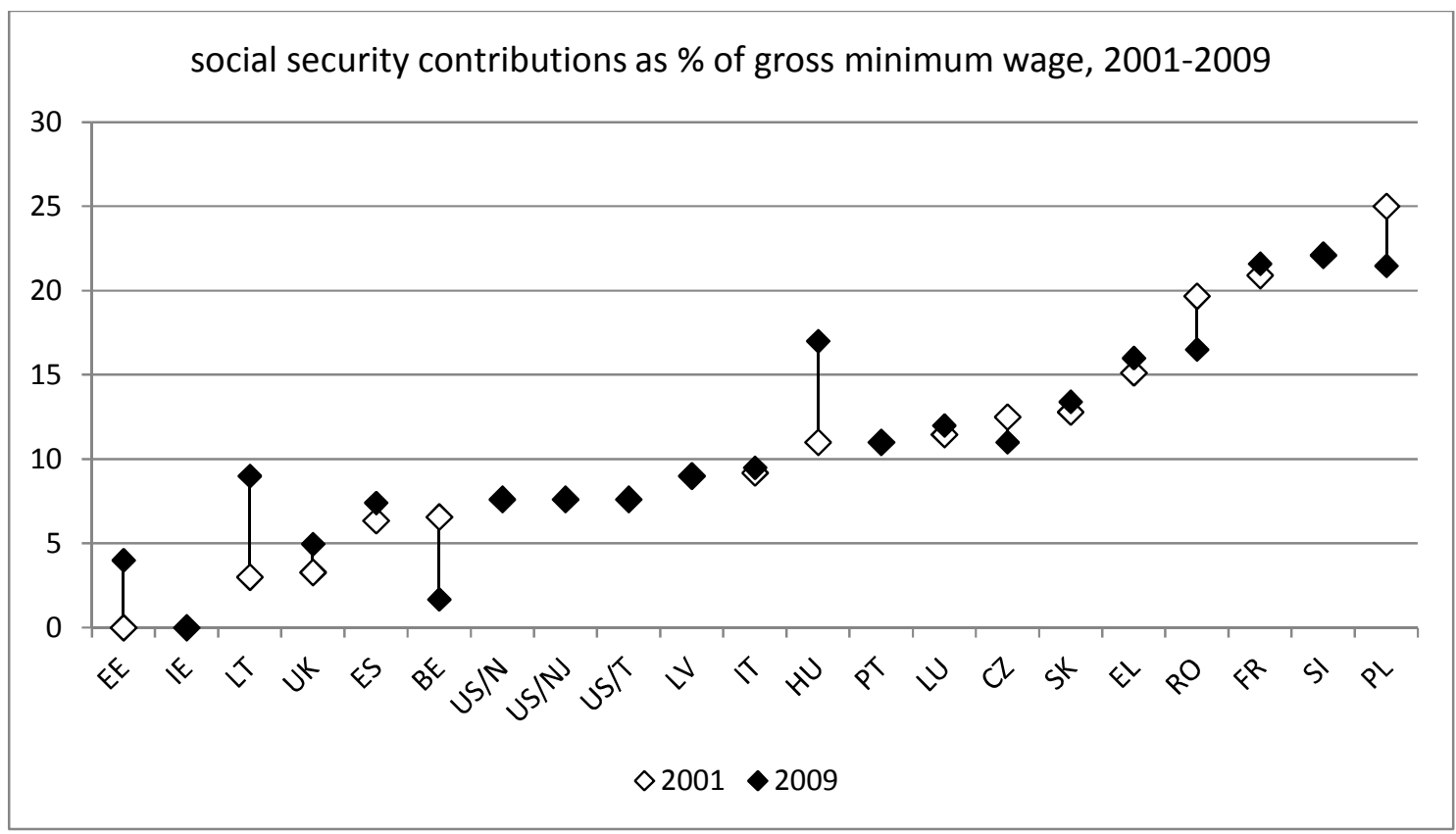

Note: gross minimum wage for a 35-year old worker. Countries are sorted by 2001 level.

Source: CSB-MIPI (Van Mechelen et al., 2011).

\subsection{Child benefits}

Child benefits have generally lost ground. For a couple with two children, the size of the child benefits package, expressed as a percentage of the gross minimum wage, declined in the majority of countries awarding these benefits. For lone parents with two children the trend was somewhat more favorable in a number of countries. The largest decreases occurred in the 
Eastern-European countries Estonia, Hungary, the Slovak Republic, the Czech Republic ${ }^{9}$ (from a rather generous level), Slovenia (couple with two children) and Latvia. On the other hand, Lithuania introduced a means-tested child cash benefit, amounting to 13 per cent of the gross minimum wage. Also in Italy, Ireland and Luxembourg, the value of child cash benefits increased. As already mentioned, the decrease of child benefits in the UK is caused by the split of the former working families' tax credit into the working tax credit and the child tax credit.

Figure 9. Trends in child benefits as percentage of gross minimum wage, 2001-2009

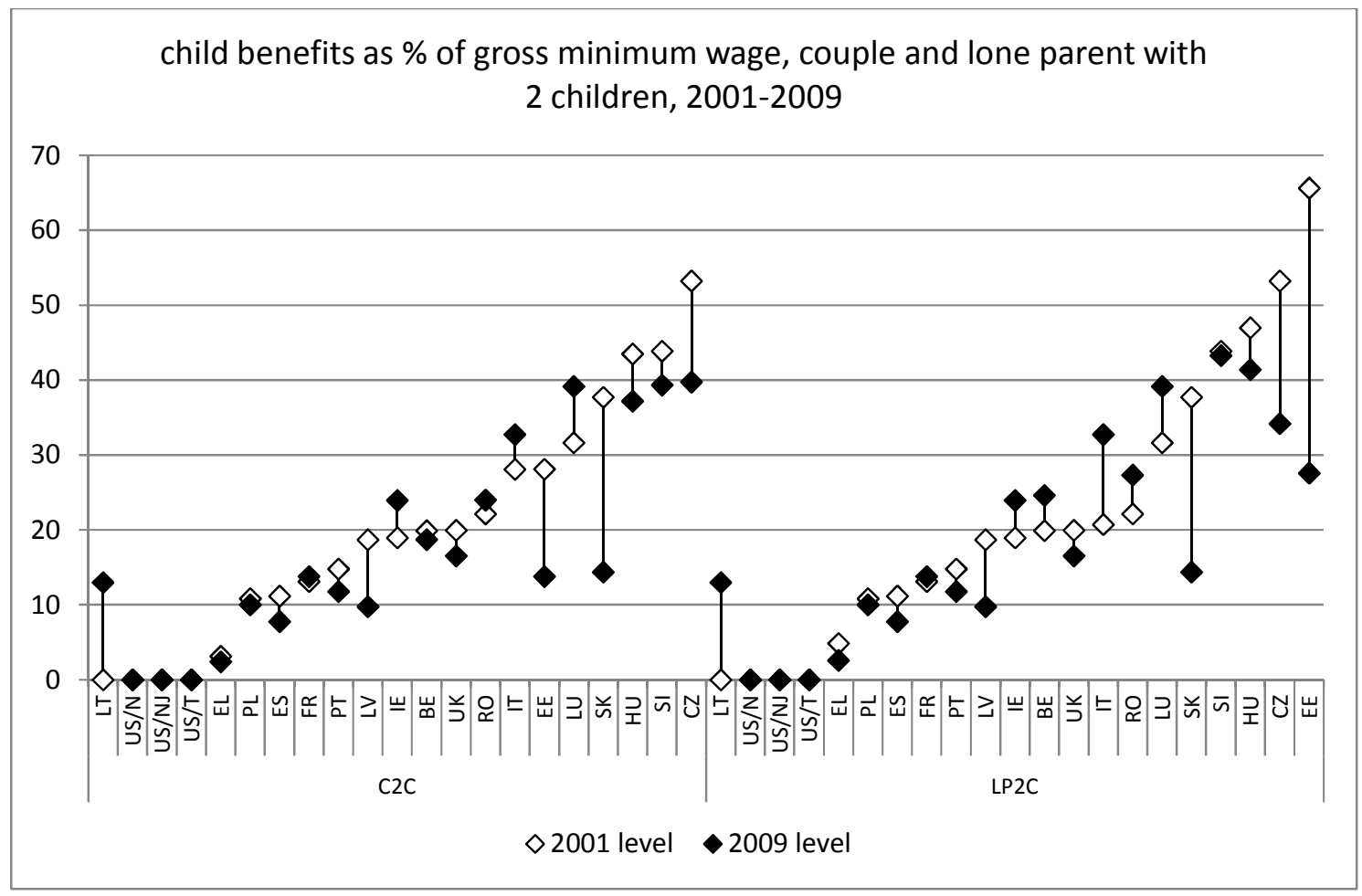

Note: gross minimum wage for a 35-year old worker

Source: CSB-MIPI (Van Mechelen et al., 2011).

The decline of child cash benefits, both in value as in their importance in net disposable income, is discussed more extensively in Van Mechelen and Bradshaw (2012).

\subsection{Other income components: housing allowance and social assistance top-up}

Two other important income components of net disposable income of minimum wage earners are the housing allowances and social assistance top-ups awarded in some countries.

In 2009, ten countries of our sample award housing allowances in order to help low income families meet housing costs. These allowances are more common and generally more substantial for families with children. A couple with two children receives housing allowances

\footnotetext{
${ }^{9}$ In the Czech and Slovak Republics compensated by a child tax credit.
} 
ranging from around eight (in Poland) to 25 per cent (in France) of gross minimum wage. Singles without children on the other hand, are only eligible in five countries, for substantially lower benefits, ranging from four (France) to 12 per cent (Czech Republic) of the gross minimum wage. Housing allowances in Latvia are exceptionally high for all family types considered, and amount to more than half the gross minimum wage.

There was no common trend in either the awarding or the level of housing allowances over the past decade. In three countries, the housing allowance decreased substantially, or was even abolished for some (or all) of the family types considered here (CZ, PL, SK). In other countries, benefit levels remained stable (FR), increased (LV, HU, SI) or became less haphazard over time (IT).

Social assistance top-ups are benefits paid by the minimum income scheme up to at least the level guaranteed by the minimum income scheme. Usually, it lifts income (somewhat) above the minimum income level, since earnings disregards apply that aim to make work pay.

Once again, it is mainly families with children that receive social assistance top-ups. The only country where single persons without dependents receive a modest social assistance top-up is in the United States, at least in two out of the three states covered here: New Jersey and Texas. Families with children, however, receive in 2009 a social assistance top-up in ten of the countries included in this study. Top-ups are less often awarded to lone parent families, more exactly in seven countries covered here. Unlike for single persons, top-ups received by couples with children and lone parents are substantial, although large variation exists between countries. For a couple with two children, top-ups range from a low of eight per cent of gross minimum wage, up to over 40 per cent in the US states and the Czech Republic, to 64 per cent in Lithuania. Top-ups for a lone parent with two children range from 16 to 32 per cent of gross minimum wage.

As with housing allowances, trends in social assistance top-ups over the past decade were fairly mixed. In two countries, family types that were eligible for a top-up in 2001 are no longer so in 2009. In the Slovak Republic, this was due to a profound tax and welfare reform whereas in Estonia, social assistance benefit levels eroded despite substantial real increases (see Van Mechelen and Marchal, 2012). In another two countries, the Czech Republic and Hungary, social assistance top-ups decreased substantially relative to gross minimum wages ${ }^{10}$. They declined only marginally or remained stable in Slovenia and the US states and increased in Luxembourg, Lithuania and Portugal ${ }^{11}$.

In France, the 2009 reform of the social assistance scheme into the "revenue de solidarite active" had as one of its main aims to make sure that employment protects against poverty (Anne and L'Horty, 2008; République Française, 2008). The rSa top-up supplements and/or replaces the previous working tax credit, and was presented under the paragraph on taxes. In

\footnotetext{
${ }^{10}$ In the Czech Republic, a reform of the social assistance scheme lowered eligibility thresholds. In Hungary, the substantial rise of gross minimum wages compared to the evolution of the social assistance threshold led to a decreasing importance of the social assistance top-up in net disposable income.

${ }^{11}$ In Lithuania and Portugal, this is a consequence of the rise of social assistance benefits. However, in both countries, respondents note that actual take-up of social assistance top-ups to minimum wages is fairly limited. The low take-up rate of the social assistance top-up in Poland, as well as numerous additional conditions, led our respondent to advise us to not include this top-up in our calculations of net disposable income.
} 
Ireland, couples and lone parents in work with children are eligible for a means-tested Family Income supplement.

\section{Conclusion and prospects for improvement}

Minimum wage floors underpin minimum income protection for workers in most countries. In 2010, twenty EU countries have a national minimum wage, set by law or through collective bargaining at the national level. The United States has a federal minimum wage and some US states set higher minimum wages. Across the EU, there is substantial variation in minimum wage levels relative to average wages, ranging from under 30 per cent to almost 50 per cent. Real increases occurred almost everywhere in the period 2001-2009, but relative to average wages the picture is more mixed. By and large the strongest increases occurred in countries with the lowest initial levels relative to average wages.

The main focus of this paper has been on net income packages at minimum wage level, taking into account the impact of taxes and social security contributions, but also benefits (including child benefits) and additional allowances. In the period 2001-2009, net incomes at minimum wage generally increased more, or decreased less, than gross minimum wages, reflecting a shift towards tax alleviation and additional income support for low-paid workers.

Net disposable incomes for full time single persons working for the minimum wage are at least as high as the 60 per cent at-risk-of poverty threshold in about half the countries of the EU where there is a minimum wage. The picture changes drastically when the focus is shifted to households with dependent children and other dependent persons. Net incomes at minimum wage for full time working lone parents are below the poverty threshold almost everywhere. For sole breadwinner couples with children net income packages at minimum wage level fall well short everywhere, generally by a very substantial margin.

What are the prospects for improvement? In some EU countries, minimum wages remain nonexistent or low relative to average wages. Thus in countries where minimum wages are presently not in place or relatively low there may be scope for gradual but substantial increases. In countries where they have deteriorated relative to average wages there may be scope for some catch-up growth. However, the route of boosting minimum wages to the upper prevailing ranges (relative to average earnings) would not be sufficient to eradicate in-work poverty, even in the absence of negative employment effects and large spill-overs to non-poor households ${ }^{12}$. Essentially that is because minimum wages have become inherently constrained in providing minimum income protection to sole breadwinner households in countries where relative poverty thresholds are strongly determined by dual earner living standards. The increases in minimum wages required to keep workers solely relying on it above the poverty threshold are in fact by now so substantial that they are hardly conceivable.

Yet minimum wages still constitute the foundation of minimum income protection for workers, and, given their role as a benchmark level, not only for those effectively working for the minimum wage. Moreover, in an encompassing anti-poverty strategy, minimum wages can play a crucial role in dampening the possible wage erosion effects of in-work benefits and

\footnotetext{
${ }^{12}$ Studies suggest that even in those cases where the overlap between low pay and household poverty is the greatest, as is the case in the United States, increases in the minimum wage have a relatively limited impact on poverty or income inequality and a substantial spill-over to the non-poor (see Formby et al., 2005; 2010). Studies for other countries suggest the same: see Gosling (1996) and Sutherland (2001) for the UK; Marx et al. (2012b) for Belgium; Müller and Steiner (2008) for Germany, Figari (2010) for Southern European countries.
} 
tax credits. This points to the importance of maintaining minimum wages and making sure that these keep pace with overall wage growth to the extent possible.

As we have seen in this paper, rather than pushing for higher minimum wages, many governments in Europe have undertaken measures to increase the net incomes of workers paid at or around the minimum wage. Minimum wage workers have generally seen their taxes fall over the past decade. In most countries, they pay very low or no taxes, especially when there are children. Only in a small number of countries have there been declines in social security contributions. There thus remains some theoretical scope for increasing net disposable incomes via this route. But even with hypothetical zero taxation minimum wage earners would in most countries not have an income sufficient to reach the poverty threshold. This is even true in countries where minimum wages are already comparatively high relative to average wages.

This brings us to the option seen to hold the most promise these days: negative income taxes or equivalent in-work benefits for low income households. As we have seen, housing allowances and social assistance top-ups already exist in a number of countries. One type of scheme, however, is garnering most interest of all: negative income taxes. Under such schemes low income households do not pay taxes but instead they get additional money through the tax system.

These still exist only in a handful of countries in any significant form, with the United States and the United Kingdom standing out in particular. The United Kingdom has implemented and extended several schemes, culminating in the Working Tax Credit (WTC). In the United States, the Earned Income Tax Credit (EITC) is now the country's pre-eminent anti-poverty program for families of working age ${ }^{13}$. Several European countries have contemplated introducing Anglo-Saxon-style tax credits, or have done so in some form, most notably the Czech Republic and Slovakia. Interest remains strong, in the public debate and in the academic literature (Marx and Verbist, 2008; European Commission, 2011; Kenworthy, 2011).

In order to be effective as an anti-poverty device, such income supplements need to be quite substantial. As this paper has demonstrated, even in countries where minimum wages are comparatively high, net incomes for lone parents and sole breadwinners with children fall far short of the poverty threshold. However, strongly targeted, generous negative income taxes are bound to create mobility traps which can only be avoided if taper-off rates are sufficiently flat. This would come at a very considerable cost given that the lower end of the household earnings distribution is so densely populated in most Continental European countries. This cost can only be avoided by making the amount of the tax credit itself smaller, but in that case the anti-poverty effect is reduced. Simulations clearly show that negative income tax schemes that work well in one particular setting do not necessarily perform equally well in other settings (Bargain and Orsini, 2007; Figari, 2010; Marx et al., 2012b).

Increasing child benefits, finally, is a route that was largely neglected over the previous decade, as Ferrarini et al. (2012) and Van Mechelen and Bradshaw (2012) document in greater detail than we have done here. It also emanates from these studies, and from other studies (e.g. Corak et al., 2005), that the best performing countries in terms of poverty

\footnotetext{
${ }^{13}$ Studies suggest that the EITC, in combination with welfare reform, produced marked increases in labour market participation, especially among single-parent households (Hotz and Scholz, 2003; Eissa and Hoynes, 2004). There is similar evidence for the British WTC (Brewer et al., 2006).
} 
reduction tend to have systems of child benefits and tax concessions that are broadly awarded yet direct resources proportionally more at the poorest.

The question of whether, how and to what extent minimum income protection for workers can be improved remains open. The debate about the question of whether minimum wages destroy jobs, or stifle job growth, is as old as the minimum wage itself. A wealth of empirical evidence has been amassed by labour economists. Some studies, like the Card and Krueger study from 1994 that concluded that minimum wage increases may effectively increase employment rather than harm it, have been among the most heatedly debated in the profession. It seems fair to state that the measured effects have sometimes been positive, sometimes negative, sometimes neutral, but never very large (Dolado et al., 1996; 2000; Freeman, 1996; OECD, 1998; 2004; Kenworthy, 2004; Neumark and Wascher, 2007). As Martin and Immervoll (2007) state: "On balance, the evidence shows that an appropriately-set minimum wage need not have large negative effects on job prospects, especially if wage floors are properly differentiated (e.g. lower rates for young workers) and non-wage labour costs are kept in check."

When it comes to effectively alleviating in-work poverty through income supplements for households mainly reliant on earnings, be it in the form of child benefits, negative income taxes or other equivalent schemes, the reality is that there are unlikely to exist cheap solutions, especially if one is also concerned about work and mobility incentives. It is also unlikely that optimal one-size-fits-all solutions exist. The socio-demographic composition of the population and particularly of the working poor matters. Child benefits, for example, will obviously have less of an effect when single person households are affected by in-work poverty, or when this is the case for multi-generation households. The distribution of wages and working hours, across the population and within households, matter greatly to the potential effectiveness and cost of negative income tax or equivalent schemes. Other elements of institutional and policy context are likely to be relevant. Future research will thus have to be oriented towards devising policy packages that optimally fit national contexts and constraints.

\section{References}

Autor, D.H., Murnane, R, and F. Levy. (2003). 'The Skill Content of Recent Technological Change: An Empirical Exploration', The Quarterly Journal of Economics, November 2003

Andre $\beta$, H. J. and Lohmann, H. (2008). The Working Poor in Europe. London: Edward Elgar.

Anne, D., and L'Horty, Y. (2008). Les effets du revenu de Solidarité active ( $r S a)$ sur les gains du retour à l'emploi (Document de recherche No. 08-11). Evry: Centre d'étude des politiques économiques de l'université d' Evry.

Barbier, J.-C. and Ludwig-Mayerhofer, W. (2004). 'Introduction: the many worlds of activation', European Societies, 6 (4): 423-36.

Bargain, O. and Orsini, K. (2007). 'Beans for breakfast? How exportable is the British Workfare Model?'. In O. Bargain (ed.) Microsimulation in action. Policy Analysis in Europe using EUROMOD. Research in Labour Economics. 25: 165-198. Oxford: Elsevier.

Boeri, T. (2012). 'Setting the minimum wage', Labour Economics, 2012, 19 (3): 281-290 (also available as IZA DP4335) 
Bosch, G. and Weinkopf, C. (eds) (2008). Low-wage work in Germany. New-York: Russell Sage Foundation

Brewer, M., Duncan, A., Shephard, A. and Suarez, M.J. (2006). 'Did working families' tax credit work? The impact of in-work support on labour supply in Great Britain', Labour Economics, 13 (6), 699-720.

Cantillon, B., Marx, I., Van den Bosch, K. and Van Mechelen, N. (2004) The Evolution of Minimum Income Protection in 15 European Countries 1992-2001 (CSB-Berichten). Antwerp: Herman Deleeck Centre for Social Policy

Cantillon, B. (2011). 'The paradox of the social investment state; growth, employment and poverty in the Lisbon Agenda', Journal of European Social Policy, 21(5): 432-449.

Card, D. and Krueger, A. B, (1994). 'Minimum Wages and Employment: A Case Study of the Fast-Food Industry in New Jersey and Pennsylvania,' American Economic Review, 84(4): 772-93

Corak, M., Lietz, C. and Sutherland, H. (2005). The impact of tax and transfer systems on children in the European Union ( IZA Discussion Paper No. 1589). Bonn: IZA

Crettaz, E. (2011). Fighting Working Poverty in Post-industrial Economies. Causes, Tradeoffs and Policy Solutions. Cheltenham, UK and Northampton, MA, USA: Edward Elgar.

Dolado, J., Felgueroso, F. and Jimeno J. (2000). The role of the minimum wage in the welfare state: an appraisal (IZA Discussion Paper No. 152). Bonn: IZA.

Dolado, J., Kramarz, F., Machin, S., Manning, A., Margolis, D. and Teulings, K. (1996). 'The economic impact of minimum wages in Europe', Economic Policy, 11(23): 319-372.

Eissa, N. and Hoynes H. (2004). 'Taxes and the labor market participation of married couples: the Earned Income Tax Credit', Journal of Public Economics, 88 (9-10): 1931-1958.

European Commission. (2010). Industrial relations in Europe 2010. Luxembourg: Publications Office of the European Union.

European Commission (2011). Employment and Social Developments in Europe 2011, Publications Office of the European Communities: Luxembourg.

Eurostat. (2011). Statistics by theme. Retrieved 8 July 2011: http://epp.eurostat.ec.europa.eu/portal/page/portal/statistics/themes

Ferrarini, Nelson, K. and Höög, H. (2012). 'From universalism to selectivity: Old wine in new bottles for child benefits in Europe and other countries'. In Marx, I. and Nelson, K. (eds), Minimum Income Protection in Flux, Palgrave Macmillan.

Figari, F. (2010). Can in-work benefits improve social inclusion in the southern European countries? Journal of European Social Policy, 20: 301-315

Fields, G. (2011). Working Hard, Working Poor: A Global Journey, Oxford: Oxford University Press.

Formby, J., Bishop, J. and Kim, H. (2005). Minimum Wages and Poverty: An Evaluation of Alternatives. Amsterdam: Elsevier.

Formby, J., Bishop, J. and Kim, H. (2010). What's best at reducing poverty? An examination of the effectiveness of the 2007 minimum wage increase. Washington DC: Employment Policies Institute. 
Fraser, N., Gutiérrez, R., and Peña-Casas, R. (Eds.). (2011). Working Poverty in Europe: A Comparative Approach. Basingstoke: Palgrave Macmillan.

Freeman, R. (1996). 'The minimum wage as a redistributive tool', Economic Journal, 106: 436, 639-649 and 842-849.

Gardiner, K. and Millar, J. (2006). 'How low-paid employees avoid poverty: An analysis by family type and household structure', Journal of Social Policy, 35: 351-369.

Goos, M., Manning, A. and Salomons, A. (2009). 'The polarization of the European Labor Market', American Economic Review 99 (2): 59-63.

Gosling, A. (1996). 'Minimum wages: possible effects on the income distribution', Fiscal Studies, 17: 4, 31-48.

Hotz, V.J. and Scholz, J.K. (2003). 'The Earned Income Tax Credit'. In R. Moffit (ed.), Means-tested Transfer Programs in the U.S., Chicago: University of Chicago Press, 141-198.

Immervoll, H. (2007). Minimum wages, minimum labour costs and the tax treatment of lowwage employment (Discussion Paper no. 2555). Bonn: IZA.

International Labour Organization. (2008). Global Wage Report 2008 / 09: Minimum wages and collective bargaining - Towards policy coherence. Geneva: International labour organization.

Kenworthy, L. (2004). Egalitarian Capitalism? Jobs, Incomes and Inequality in Affluent Countries. New York: Russell Sage Foundation.

Kenworthy, L. (2008). Jobs with Equality, Oxford: Oxford University Press

Kenworthy, L. (2011). Progress for the Poor. Oxford: Oxford University Press.

Lohmann, H. and Marx, I. (2008). 'The different faces of in-work poverty across welfare state regimes'. In Andre $\beta$, H.J. and Lohmann, H. (eds.), The Working Poor in Europe. London: Edward Elgar.

Lohmann, H. (2009). 'Welfare states, labour market institutions and the working poor: a comparative analysis of 20 European countries', European Sociological Review, 25 (4): 489-504

Lucifora, C. and Salverda, W. (2008). 'Low pay', in: W. Salverda, B. Nolan, T. Smeeding (eds.), Oxford Handbook of Economic Inequality. Oxford: Oxford University Press.

Maitre, B., Nolan, B. and Whelan, C.T. (2011) 'Low Pay, In-Work Poverty and Economic Vulnerability: A comparative Analysis using EU-SILC', The Manchester School, 80: 99-116

Marlier, E., Natali, D. and R. Van Dam (2010), Europe 2020 : Towards a More Social EU? Brussels : Peter Lang.

Martin, J. P., and Immervoll, H. (2007). 'The minimum wage: making it pay'. OECD Observer, 261.

Marx, I. and Verbist, G. (1998) 'Low-paid work and poverty: a cross-country perspective'. In Bazen, S., Gregory, M., and Salverda, W. (eds) Low-wage employment in Europe, Cheltenham: Edward Elgar. 
Marx, I. and Verbist, G. (2008). 'Combating in-work poverty in Continental Europe: the policy options assessed'. In Andre $\beta$, H.J. and Lohmann, H. (eds.), The Working Poor in Europe. London: Edward Elgar.

Marx, I., and Nolan, B. (forthcoming 2012). 'In-work poverty'. In B. Cantillon and F. Vandenbroucke (Eds.), For Better, For Worse, For Richer, For Poorer. Oxford: Oxford University Press.

Marx, I., Vandenbroucke, P. and G. Verbist (2012a). 'Can higher employment levels bring down poverty in the EU? Regression based simulations of the Europe 2020 target', in Journal of European Social Policy (also available as IZA DP6068)

Marx, I., Vanhille, J., Verbist, G. (2012b). 'Combating in-work poverty in Continental Europe: an investigation using the Belgian case', Journal of Social Policy 41 (1): 19-41

Müller, K.-U. and Steiner, V. (2008). Would a legal minimum wage reduce poverty? A microsimulation study for Germany (DIW Discussion Paper No.791). Berlin: DIW

Neumark, D. and W.L. Wascher (2007), 'Minimum Wages and Employment', Foundations and Trends in Microeconomics, vol. 3, no. 1+2, pp 1-182, 2007.

Nolan, B. and Marx, I. (2000). 'Low pay and household poverty'. In Gregory, M. et al. (eds.), Labour Market Inequalities: Problems and Policies of Low-wage Employment in International Perspective. Oxford: Oxford University Press.

Notten, G. and de Neubourg, C. (2011). 'Monitoring absolute and relative poverty: "not enough" is not the same as "much less"', Review of Income and Wealth, 57(2): 247-269

OECD (1998). Employment Outlook. Paris: Organisation for Economic Co-operation and Development.

OECD. (2002). Benefits and wages. Paris: OECD.

OECD (2004). Employment Outlook. Paris: OECD.

OECD (2006). Employment Outlook. Paris: OECD.

OECD (2007). Employment Outlook. Paris : OECD.

République Française (2008). Livre vert vers un revenu de Solidarité active. Available from http://www.ladocumentationfrancaise.fr/var/storage/rapportspublics//084000138/0000.pdf

Salverda, W., Van Klaveren, M., van der Meer, M. (eds) (2008). Low wage work in the Netherlands, New York: Russell Sage Foundation.

Standing, G. (2011), The Precariat: The New Dangerous Class. London and New York: Bloomsbury Academic

Sutherland, H. (2001). The national minimum wage and in-work poverty (DAE Working Papers MU0102). Cambridge: University of Cambridge.

United States Department of agriculture, food and nutrition services (2010). Reaching those in need: state supplemental nutrition assistance program participation rates in 2008: summary. $\quad$ Retrieved August 2011 from : http://www.fns.usda.gov/ora/menu/Published/snap/SNAPPartState.htm

U.S. Bureau of the Census, and Bureau of Labour Statistics. (2011, December 11). Current Population Survey Annual Social and Economic Supplement. Retrieved December 2011, from http://www.nber.org/data/cps_progs.html 
Vandenbroucke, F. and Vleminckx (2011), Disappointing poverty trends : Is the social investment state to blame?, Journal of European Social Policy, 21: 432-449.

Van Lancker, W. (2012) The European world of temporary employment: gendered and poor?, European Societies (forthcoming)

Van Mechelen, N., Marchal, S., Goedemé, T., Marx, I., and Cantillon, B. (2011). The CSB Minimum Income Protection Indicators dataset (CSB-MIPI) (WP No. 11/05). Antwerp: Herman Deleeck Centre for Social Policy.

Van Mechelen, N. and Bradshaw, J. (2012). 'Child benefit packages for working families, 1992-2009'. In Marx, I. and Nelson, K (eds). Minimum Income Protection in Flux, Palgrave Macmillan.

Van Mechelen, N. and Marchal, S. (2012). 'Social assistance benefits: Trends 1992-2009'. In Marx, I. and Nelson, K. (eds), Minimum Income Protection in Flux, Palgrave Macmillan.

Vaughan-Whitehead, D. (2010). The minimum wage revisited in the enlarged EU. Cheltenham: Edward Elgar.

Visser, J. (2011). The ICTWSS Database. Retrieved 14.7.2011, from Amsterdam Institute for advanced labour studies (AIAS), University of Amsterdam: http://www.uvaaias.net/207

Weishaupt, T. (2012). 'A common turn to activation?'. In Marx, I. and Nelson, K. (eds.), Minimum Income Protection in Flux, Palgrave Macmillan.

Wirtschafts- und Sozialwissenschaftliche Institut. (2011). Datenbank Tarifabschlüsse (Retrieved July 2011, from Wirtschafts- und Sozialwissenschaftliche Institut: http://www.boeckler.de/apps/tarifabschluesse/index.php 